\title{
A ROOM WITH A VIEW: WINDOW IMAGES AND 'OPEN IMMANENCE' IN THE WRITINGS OF ADOLPHE RETTÉ AND G.K. CHESTERTON
}

\author{
Brian Sudlow*
}

\begin{abstract}
Adolphe Retté and G.K. Chesterton often use the image of a window, a paradox given the widespread view that Catholic writers are usually closed minded. This article asks whether Charles Taylor's philosophy of the individual could explain this paradox more satisfactorily. Chesterton's windows express a realist epistemology, while Retté's windows express the illumination of faith. The themacity of the subject in their writings, however, shows that their windows give expression to Taylor's 'open immanence', rather than Taylorian 'porosity'. Their reactionary character can be interpreted as a kind of Taylorian 'buffering' which is necessary for believing writers resisting secularity.
\end{abstract}

Throughout his writings wonder at the quotidian was one of G.K. Chesterton's greatest creative drives. His I9I2 novel Manalive, for example, portrays the figure of Innocent Smith, a man in constant pursuit of the wondrous hidden under the guise of the workaday. ${ }^{1}$ Earlier, Chesterton's Tremendous Trifles, a collection of newspaper articles originally published in the Daily News, contained essays on 'A Piece of Chalk', 'What I found in my pocket', and 'The Toy Theatre'. 'A subsequent collection published in I9 Io included articles entitled 'On Gargoyles', 'The Wheel' and 'Cheese'. The study of the inner poetry of prosaic artefacts was a corollary of Chesterton's theodicy through which he found in the natural world evidence of a meaningful, divinely created cosmos. ${ }^{4}$ His life-long commitment to this agenda illustrates not only his desire to push beyond the limitations of the positivist

\footnotetext{
*Aston University. c/o: 47 Ashworth Street, Failsworth, Manchester M35 oJQ, UK. Email: sudlow.brian@gmail.com

Literature \& Theology (C) The Author 20I I. Published by Oxford University Press 20I I; all rights reserved. For Permissions, please email: journals.permissions@oup.com
} 
or empiricist imagination (or lack thereof), but also, thereby, to suggest the compatibility of discursive reason with intuitive faith.

Among all these objects of daily experience, however, the one that arguably piqued Chesterton's curiosity the most was the window. ${ }^{5}$ This fascination began when, as a child, he noticed that the world seemed larger if viewed through the apparently confining lines of a window frame. It was in fact the frames and limits of windows which suggested to Chesterton the fragments of what would later become a kind of rough philosophy. The Chestertonian window signifies prima facie his paradoxical belief that fixed dogma facilitates rather than blocks human understanding of the world. Such a position already sets him apart as a rebel against a range of epistemological assumptions underpinning the Enlightenment project. At the same time it also represents an attempt to reassert faith as a species of knowledge and not simply as a moral engagement.

Readers of G.K. Chesterton's oeuvre will find his curious preoccupation with windows paralleled in the work of French Catholic author Adolphe Retté. Retté's interest in windows can be seen across his writings. In his memoirs and his fiction, Retté or one of his characters often approaches a window at moments of emotional or moral tension, or of critical, spiritual insight. ${ }^{6}$ Windows, for Retté, are not so much paradoxical symbols, as physical markers which point beyond the visible domain. They are signs of vision or thought, which trigger or facilitate the understanding of eternal verities.

This imaginative coincidence might be considered insignificant, especially since there is no evidence of intertextual influence between Chesterton and Retté. Retté, moreover, is arguably a much less significant comparative counterpart for Chesterton than Charles Péguy or Paul Claudel. Nevertheless, Rette remains a crucial figure in the Catholic revival, not only because his trajectory from anarchist and symbolist poet to monarchist and Catholic writer is emblematic of the path taken by many French writers of the period, but also

30 because his output (poetry, journalism, memoirs, novels, literary criticism, spiritual treatises, etc.) touches on a great many of the concerns which French Catholic authors express with regard to one or other of the forms of secularisation. ${ }^{7}$

The fact that Chesterton's concerns with secularisation are as broad and 35 varied as Retté's, points to something deeper in this curious figurative convergence between the imaginations of these two writers. Accounts of the Catholic literary movements in France and England at the beginning of the 2oth century are generally agreed on the reactionary nature of Catholic thought during this period and on the burgeoning influence of Vaticansponsored Thomistic philosophy, or, as Thomas Woodman more accurately remarks, 'particular interpretations' of Thomism. ${ }^{8}$ Critical consensus also takes for granted the inward-looking character of late I9th- and early 2oth-century 
Catholic thought, especially in the face of Enlightenment philosophies, scientific developments and historico-critical methods of biblical exegesis. ${ }^{9}$ Yet Chesterton, as his biography of Thomas Aquinas demonstrates, would have contested such a negative view of Thomism, at which he felt the 2oth century 5 was clutching precisely because it had abandoned reason. ${ }^{10}$ Indeed, Chesterton would have argued, like Jacques Maritain or Etienne Gilson, that Thomistic philosophy had the capacity to engage robustly with the difficulties of modernity, especially in the field of epistemology. Moreover, the imaginative figure of the window itself is suggestive of something which is not inward but outward looking. For Chesterton and Rette, the window is not an occasion of dangerous exposure to the outside world, but a point through which the outside world can be observed with the reliable eyes of sound philosophy and Christian faith. It could be argued in fact that this vitreous perspective correlates not with the ingressive processes of reaction or counterrevolution but with the egressive virtues of observation, receptivity and enlightenment.

From a methodological point of view, speaking of reaction evokes a cultural or political line of analysis which is likely to be circular in nature; since neither Chesterton nor Retté espouse Enlightenment epistemologies, their windows might be assumed to be boarded up. Indeed, the very term reaction, a corollary of hegemonic progressivism, already involves to some degree an unscientific exoticising of the phenomenon it describes. Instead, the distinction of outward-inward conjured by Rette's and Chesterton's image of the window can be more fruitfully approached from perspectives found in Charles Taylor's monumental work A Secular Age. According to Taylor's analysis, the pre-modern individual is 'porous' with respect to the meaning and purpose of a divinely designed cosmos outside the mind; the modern individual, in contrast, constructs understanding of the cosmos from the inside outwards, in ways that 'buffer' individual identity from the exceptionless and purposeless cosmic laws without. ${ }^{11}$ To place the Chesterton-Retté window in the context of the 'secular age' which Taylor describes could also bring to the foreground the secularising cultural and religious dynamics that shaped the creative explosion represented by the French and English Catholic literary revivals. If the term reaction comes from the language of hegemonic modernity, the term secularisation at the very least will allow us to follow the grain of Chesterton's and Retté's imaginations in their revolt against what they saw as the declining influence of Christianity.

The importance of this analysis to secondary literature is also tangible. The Taylor Effect: Responding to a Secular Age, a collection of papers given at a 2009 international conference on Taylor's A Secular Age, hardly touches on questions of literature. ${ }^{12}$ Moreover, while Graham Ward has argued that 'literature resists secularity', both through the cultural connotations of our linguistic and imaginative resources, and through the literary dynamics of make-believe, 
Chesterton's and Retté's window image suggest a further dimension to literature's capacity to undermine the secular. ${ }^{13}$

This article proposes, therefore, to explore the ways in which the problem of inward-outward, as symbolised by Chesterton's and Retté's windows, can be illumined by Charles Taylor's analysis of the individual. In doing so, it will aim to suggest further ways in which literature can resist secularity, and to draw conclusions about the paradoxical nature of Catholic reaction to secularisation by relating it to Taylor's understanding of individual porosity or buffering. Let us begin, however, by considering Chesterton's and Retté's backgrounds and some of the writings in which they speak about windows.

\section{Chesterton, Retté AND The imAgE OF THE WINDOW}

The construal of the window image as a symbol of the movement from inward to outward is powerfully inscribed in Retté's and Chesterton's personal trajectories. Both writers felt the impact of subjectivist philosophies on their thought and work before developing more objectivist perspectives on the world. Throughout the late i 880 s and the I890s, for example, Retté moved in Symbolist literary circles in Paris. According to his biographer Cornell, this was a period for Retté when 'dream was much more important than reality, when artificiality was a form of art, and when idealism wandered far beyond the boundaries of everyday existence'. ${ }^{14}$ This epistemological subjectivism took on a nihilist form within his growing corpus of poetry, revealing his preoccupation with the decadent themes of death and sex. ${ }^{15}$ Likewise, on the moral plane Retté's subjectivism underpinned an individualistic lifestyle of riotous behaviour in the bars and brothels of Belle-Époque

25 Paris, a period he describes in his 1903 memoir Le Symbolisme, anecdotes et souvenirs. ${ }^{16}$

Nevertheless, Retté's conversion to Catholicism in I906 came some years after he had moved away from literary decadence and into the ranks of revolutionary syndicalism. In a steadily centrifugal movement, Retté's studied in-

30 teriority and self obsession in the I 880 os gave way in the I89os to a larger preoccupation with the living conditions of the workers and then, after the turn of the century, to a holistic vision in which spiritual, political and cultural concerns all fell within the ambit of his newly found Catholic faith. His association with the monarchists of Action Française before the First World 35 War was a sign of the radical transformation of his political views, which still allowed space for his new preoccupation with themes of Catholic spirituality and social action. ${ }^{17}$

Chesterton's dalliance with subjectivism was shorter and less tumultuous, though, nevertheless, deeply formative. In his Autobiography Chesterton is hardly explicit about what form this subjectivism took. In some respects it 
must have been psychological or philosophical in nature; for example, he places it in the context of a late-teenage crisis involving 'doubts and morbidities and temptations'. ${ }^{18} \mathrm{He}$ dabbled with spiritualism for a time, and in what he calls a 'congestion of imagination' found himself capable of mentally conjuring up the very worst of horrible crimes. ${ }^{19}$ Unlike Retté, however, Chesterton claimed never to have worked out such morbidities or temptations in his conduct, especially not in matters of sexuality. In a letter to his wife, for example, one of the four things he states that he is thankful for is that he had 'never gone after strange women'. 20

In a recent study William Oddie has explored this period and found it to be one in which Chesterton, if he felt the shadow of subjectivism, grappled with it both philosophically and morally. Oddie's analysis of some hitherto unexplored sources persuasively shows that Chesterton's encounter with literary and artistic decadence, especially in the circles associated with the Slade School of Art where he was a student, gave him an originary experience of evil that he would never forget. ${ }^{21}$ This was not Chesterton's initiation into some mere petit bourgeois moralism but his discovery that a moral teleology shaped by inward-looking, egocentric criteria involved a rupture with the sources of moral goodness. Chesterton's characteristic jollity thus provides its own commentary on his conviction that subjectivism's worst sin was the pessimism it engendered. $^{22}$ For Chesterton, as his later writings demonstrate, the task of the culture wars was to find the way out from the philosophical and moral locked-in syndrome that he experienced during this period.

This movement inward-outward, suggested by Retté's and Chesterton's personal trajectories, is also evoked by their contribution to the Catholic literary project of reconciling reason and sentiment. As George Shuster argues, the Catholic literary revivals of the late Igth and early 2oth centuries sought their intellectual superstructure in a reaction against the secular corollaries of Voltairean rationalism and of Rousseauian romanticism. ${ }^{23}$ By splitting the intellectual sources of understanding from the emotional, these fragmentary, secularising tendencies were contested by the Catholic literary imagination, which held, as two of its fundamental suppositions, that humans were capable of knowing God and the world objectively, and that moral sentiment and human choice were ontologically anchored.

In pursuit of this inward-outward balance, Retté's and Chesterton's writings frequently explore the reconciliation of the objective content of reason with an interior moral sense. For example, in his spiritual memoir Du Diable à Dieu (I907) Retté traces the convergent lines of his rational examination of Catholic belief and the difficult moral drama that led him finally to conversion. He recounts, on the one hand, how he deliberated carefully the respective virtues of various religions and philosophies, while he experienced, on the other hand, a dreadful interior dialogue in which he perceived three 
voices - those of a demon, an angel and himself-arguing over his fate. ${ }^{24}$ Retté, as a long-time student of his interior life, became sensitive to the mystical tensions of spirituality, and wrote eloquently about them in several works. $^{25}$ Yet he also became actively engaged as an apologist of the Catholic cause during the difficult years following the Separation of Church and State. ${ }^{26}$ His inward terrain of spiritual experience was thus charted against an outward map that, for Retté, was inexorably objective and illumined by public Christian belief. What had been an inward, purposeless realm of dreamlike experience came to be structured by outward Christian revelation concerning the nature of temptation, sin, grace and mystical illumination.

Chesterton, for his part, strives consciously in his many varied writings to meld the imagination and intuition of the romantic tradition with the realism, common sense and logic of the rationalist tradition. Here he too seeks a balance between outward knowledge in its objectivity and intuitive, inner moral insight. Chesterton was in fact convinced that the human mind was stereoscopic, guided by reason but open and sensitive to the emotional, supra-rational or mystical paths of knowledge. ${ }^{27}$ This was one of the many paradoxes which, for Chesterton, made up the scope and structure of a reality which, if viewed monoscopically, could only be misunderstood. ${ }^{28}$ In fact, the necessity of the subject's stereoscopy resulted purely from the objectively paradoxical structure of Christian revelation. Maintaining the balance between apparently contradictory forces - chastity and fruitfulness, faith and reason, intelligence and sentiment-was, according to Chesterton, the Church's special achievement. ${ }^{29}$

Given the themacity of this inward-outward distinction in Retté's and Chesterton's respective trajectories and intellectual positions, it is more than a curious coincidence that both writers should frequently have had recourse to the image of the window. Windows for both Rette and Chesterton are suggestive of the reconciliation of inward experience and outward knowledge or 30 belief within the wider project of Catholic literary creativity and thought. Following Ward, we could interpret this coincidence simply in terms of the common magma of images from which writers of all stripes have produced literature haunted by the implications of the transcendent and the universal. ${ }^{30}$ It could thereby be argued that the coincidence of this image should not be seen as a reflection of some common dogmatic source since the associations and disassociations of the imaginary are beyond control. ${ }^{31}$

There are, nevertheless, richer nuances, differences and compatibilities in Chesterton's and Retté's use of the window image that suggest that the magma of associations is indeed susceptible to greater literary control. For 40 Chesterton, for example, the window is principally an image expressing epistemological suppositions. The window allows the outside world to penetrate the inner subject, while allowing the inner subject to know directly the outer 
world. In an essay on St Thomas More, it is precisely this capacity to see things as they are which Chesterton uses to distinguish More from Henry VIII: 'A mind like More's was full of light like a house made of windows; but the windows looked out on all sides and in all directions. ${ }^{32}$ This image, found here in a late essay, had long been part of the Chestertonian imagination. In the dedication of The Ballad of the White Horse (I9I I) he associates the historicity of the life of Alfred the Great with the fact that Alfred too looked 'On peopled plains and skies that lower / From those few windows in the tower / That is the head of a man'. 33 According to Chesterton, More's ability to see out 'on all sides', gives him the advantage of objectivity over the reckless subjectivism of his king. Likewise, Alfred's ability to look through the windows of his eyes on the outside world lends his experiences a veracity which might otherwise seem improbable in epic poetry.

There is, moreover, a theological dimension in Chesterton's use of the window image. One important Chesterton window text is his Ballad of Saint Barbara, which juxtaposes the legend of Saint Barbara with images of the first Battle of the Marne. While it expresses some understandable military and tactical reservations about windows, it evokes their figurative capacity to depict human access to the very meaning of those things that lie outside the mind. In this text, furthermore, such meanings are brought to light from a specifically Christian perspective. Barbara's father had intended to put two windows in the tower where she was living in seclusion, but in his absence Barbara, a recent Christian convert, orders the builders to make three windows in honour of the Trinity. Chesterton renders her explanation thus: 'But out of the third lattice / Under low eaves like wings / Is a new corner of the sky / And the other side of things. ${ }^{34}$ In addition to Chesterton's preoccupation with the human capacity for objective knowledge, we see here, in Platonic language, his concern about the meaning of the cosmos as it is made available by Christian faith. The windows allow access to the other side of things but only now through a Trinitarian configuration.

Arguably, the key to all these window images in Chesterton's writings is found in his Autobiography:

All my life I have loved frames and limits; and I will maintain that the largest wilderness looks larger seen through a window. ... I believe that in feeling these things from the first, I was feeling the fragmentary suggestions of a philosophy I have since found to be the truth. ${ }^{35}$

Chesterton goes on to explain that this philosophy is ultimately the only justifiable grounds on which one can consider oneself free to think. Chesterton's window is essentially an image undermining epistemologies that would either (i) lock the human mind in on itself, such that what it 
knows is not the object but the idea that the subject has of the object; or (ii) limit knowledge of the object to the physical or empirical domain, such that no ultimate meaning or purpose is available in the object. The window image in this respect is one more Chestertonian paradox: the constraints of the window in the trans-mural fissure are what facilitate and liberate our vision or understanding.

Adolphe Retté's use of the window image is arguably more redolent of the theological use Chesterton makes of it in the Ballad of Saint Barbara, and at the same time presupposes the possibility of the human mind knowing reality as it 10 is. In Retté's memoirs and novels, as we have noted, the image of a window often appears at moments of great emotional stress or spiritual insight. In Retté's 1908 novel Le Règne de la Bête, Charles, a would-be anarchist bomber, gazes through a window as he struggles with the prospect of bombing the cathedral of Notre Dame in Paris. ${ }^{36}$ He presses his forehead against the

15 glass in a gesture which Retté himself repeats when, a few years later in a house on the hill of Fourvière in Lyon (the capital of Catholic France), he begins a meditation on the role of the saints in the destiny of the French nation. ${ }^{37}$ In these cases Retté's window appears to evoke the subject's capacity to see beyond himself, or indeed to see beyond the immediate, to the mystery that lies beneath it. For Charles this mystery is not so much the object of faith, as the divine appeal not to pursue his murderous path. Charles is called out of his subjectivist plotting into contact with an objective moral injunction (though experienced interiorly) not to commit murder. For Retté, in contrast, this mystery beyond the window is the faith-perceived role of the saints as the protectors of Catholic France against its secularist traitors.

The most significant of these Rettean windows, however, appears in Dans la Lumière d'Ars, a book of memoirs and personal reflections written after Retté had made a trip to the shrine of Saint Jean Vianney and attended a retreat at the abbey of Notre Dame d'Hautecombe by Lake Bourget in

30 Savoie. On the evening before his departure Retté finds himself in contemplative mood:

Je remontai dans ma cellule, après le Salve Regina, et je me mis à la fenêtre. La beauté du paysage nocturne me cloua....La lune, en son plein, monte lentement dans le ciel pur et dépasse les sommets....Tout est apaisement, recueillement, prière. Moi aussi, je prie en union avec ce paysage de songe. J'adore le grand Artiste qui le créa. ${ }^{38}$

This passage exhibits the connotations we discerned in his other windows and also shows how, by this time, Retté had passed definitely from the interior isolation of the subjectivist to a habitual, outward communion with the Catholic God. If the landscape is dreamy, it is no longer so in some 
Symbolist sense, but in a way that is suggestive of an objective, creative purpose. As Chesterton's window is a sign of the escape from idealist or empiricist epistemologies, so Retté's window is a sign of the passage from purely rational to supra-rational modes of knowledge that remain, nevertheless, rooted in the subject's experience of a meaningful and purposeful cosmos. If Chesterton's window stands most often for the possibility of objective human knowledge, Retté's window stands for the possibility that such knowledge can be elevated to a transcendentally theological level.

We can evoke two possibilities as the source of Retté's fascination with window views. In $A u$ Pays des lys noirs Retté observes that Immanuel Kant used to work by his office window from which he could see a fir tree whose movements inspired his thought processes. ${ }^{39}$ Since Retté loathed Kant's philosophy, it is tempting to read Retté's window as a studied symbolic subversion of Kant's idealism; unlike Kant's window, Retté's window does not lead to an idealist enclave of the speculative intellect, but to a freedom in which the mind can really encounter God. Another possible source of this image lies in a vision experienced by St Benedict, the 6th-century founder of western monasticism. According to St Gregory the Great, Benedict was gazing from a window in his cell when all of a sudden the whole world was held before his eyes and he saw the soul of St Germain taken up to heaven. ${ }^{40}$ As a hanger-on in monasteries after his conversion, Retté would very probably have known this story. Neither hypothesis is, however, conclusive.

If then we concede a common dogmatic source for this image of the window as deployed by Chesterton and Retté, could it simply be the result of imposing the story of the anti-Enlightenment on imaginations beset by the anxieties of modernity? And, in this case, are we not still faced with the ostensible tension between the openness and receptivity the window conjures and what might be seen as the closed philosophical and ecclesiological connotations Chesterton and Retté find in it? If, to use one extraordinary image of Chesterton, the window is a figure of the problem of 'pontifical man' whose reason came loose when his mitre was pulled off his head at the Reformation, then Retté's and Chesterton's agendas appear only to be paradoxical attempts to subvert Enlightenment scepticism about the possibilities of human knowledge. ${ }^{41}$

II. POROSITY, BUFFERING AND 'OPEN IMMANENCE'?

\section{A TAYLORIAN ANALYSIS}

Another way of addressing this issue is to re-examine the window image from the perspective of Charles Taylor's philosophy of the individual. Building on concepts he began to elaborate in early studies, Taylor brought his thinking to a head in A Secular Age, a monumental work for which he was awarded the 
prestigious Templeton Prize. ${ }^{42}$ Therein Taylor seeks to analyse and synthesise a wide variety of accounts of secularisation concerning the individual, society and the Church. The wider pertinence of Taylor's work to readings of Retté and Chesterton comes precisely from the perspectives it gives on the difficulties which secular developments pose to faith. Still, it is through his conceptualisation of the individual, and of how subjects relate to the universe around them, that his analysis casts light on the image of the window in the writings of Retté and Chesterton.

Taylor describes two models of the individual in relation to the sources of existential meaning, the explicatory power of which leads the individual to a sense of fullness. The first of these models is the pre-modern individual whom Taylor labels as 'porous'. Individual porosity, he argues, is characterised epistemologically by the notion that meaning and purpose are exogenous to the individual. The metaphysical corollary of this conviction is that the cosmos itself is charged with meanings and purposes that impose themselves on the individual from without. The universe is enchanted, and human porosity thereto is also characterised by a vulnerability to outside agencies, whether divine, angelic or demonic. In fact, the moral purposes of the cosmos are precisely the agendas of these agencies. What Taylor is here describing is how Western culture saw the world before the Weberian Entzauberung der Welt. Belief before the early modern period, whether we are considering official Magisterial faith or the admixture of paganism and Christianity that sometime characterised the peoples of Western Europe, can be seen thus as an exercise of this porosity. ${ }^{43}$

Taylor contrasts this model of porosity with what he calls the 'buffered' individual. From the early modern period a different model of individuality has emerged under a variety of forces, ranging from the fragmentation of Christian belief to the development of the physical sciences, the advent of epistemological scepticism and a culture in which individuality took on an increasingly important role. Knowledge of the cosmos came gradually to be considered as an endogenous construction of the mind. The outside cosmos thereby was not a province invested with meaning and purpose by a variety of spiritual agencies, but rather a system of impersonal and exceptionless laws. Purpose too was generated inside an inner boundary-a buffering zone35 where the human mind met the purposeless cosmos not passively but creatively. What characterises the buffered individual for Taylor is the capacity to be disengaged from what is outside the mind. ${ }^{44}$

Taylor's distinction of porosity-buffering has a prima facie application to the problem of inward-outward as expressed by the image of the window in Rette's and Chesterton's imaginations. The view that knowledge is shaped by an experience of meaning located exogenously outside the mind suggests that Chesterton's window could be seen as a porous device. Retté's window too 
communicates strongly the suppositions of porosity by conjuring up the encounter between the human mind and divine meanings and purposes as revealed by public Christian revelation. At the same time, the window could be taken as an indictment of the buffered individual and his subjectively generated knowledge. Paradoxically it is the buffered individual who is inward looking because his understanding of the cosmos is mind-centred and endogenous to the intellect.

Still, we encounter two problems here. First, Taylor's view is that individual porosity depends on a naivety no longer available after the advent of the buffered individual. Everyone now is in a sense buffered because everyone understands implicitly the possibility of disengagement. The second problem lies with Chesterton and Retté. As we have seen, Chesterton's view of knowledge posits that it is not purely rational but also mystical or sentimental. Knowledge results not only from ratiocination about phenomena but also from intuition of the cosmos's noumena; this intuition, however, is suggestive of the importance Chesterton accords to some interior sense within the individual. Likewise, Retté's view of revelation is not exclusively public but remains sensitive to the charismatic movements that signal God's direct intervention within individuals, whether believers or unbelievers. The interior terrain of Retté as an individual is shaped not only by what comes from without, but also by what unfolds within. Regardless, therefore, of how we regard Chesterton and Retté, we cannot simply classify them as porous individuals in the Taylorian sense, nor assign to their windows the simple symbolic value of porosity.

Taylor's analysis, however, goes beyond a simple binary distinction of porosity and buffering. For Taylor, as we have noted above, believers and unbelievers under the conditions of modernity begin from a context of buffering Taylor also calls the immanent frame. ${ }^{45}$ While in the context of societal secularisation the buffered individual's mind-centred view of the universe tends towards unbelief, it is still possible for the believer within the immanent frame to escape its inherent insularity and to be open to something transcendent. The closed world structures, which the buffered individual seems naturally to embrace, are thus subverted by what Taylor calls 'open immanence' or by what we could describe as a partial recovery of porosity. In other words, from within the buffered mind the individual can still come to perception of, and a conviction about, exogenously located meaning and purpose.

Now this conceptualisation of qualified porosity or 'open immanence' facilitates another reading of the Retté-Chesterton window by which it symbolises a conscious inwardness opening itself to the outside. As modern individuals Retté and Chesterton are sensitive to the interior arena buffering produces, but arguably they seek, literally through the window, to escape a 
buffered, mind-centred view of the cosmos. For both these writers in different ways the window expresses the possibility of the experience of transcendence, even when they operate within a supra-rational framework. In this light Chesterton's confidence in the human mind is not a simplistic refusal of the Enlightenment, so much as a vote of confidence in the very possibility of the mind being illumined by what is without. Likewise, Rettés readiness to let theology inform his mind is a retrieval of meaning located exogenously in a public revelation. We need not settle here the issue of which meaning or what illumination is produced. For both these writers, as for others, the window

10 declares that meaning and purpose are received and embraced by the subject's mind from without, rather than simply constructed or engendered from within.

\section{CONCLUSIONS AND COROLLARIES}

It might be thought that this window image contradicts prima facie the Pauline framing of faith as seeing 'through a glass' darkly. ${ }^{46}$ Arguably, however, it is an attempt not to dissolve the difference between faith and the beatific vision, but to affirm the cognitive dimension of faith during a period in which secularism was reducing faith to a purely moralistic fideism.

One corollary of this argument about buffering and porosity is that Graham Ward's analysis of how literature resists secularity remains within a buffered framework. From what is arguably a postmodern perspective Ward bases his case for literature's resistance to secularity on the religious connotations of our imaginary and linguistic resources and on the suggestiveness of transcendence that all narrative articulates. ${ }^{47}$ Both these conditions, however, are 'buffered' in their implications. Chesterton's and Retté's windows aim rather to surmount the buffered narrative process (of closed immanence) in which the magma of the imaginary is beyond control (a process suggesting, after Freud, the subject's loss of self mastery), to propose instead not the transcendent implications of the stories we tell ourselves, but the very possi-

30 bility of God telling us God's own story, whether through nature or through revelation.

If this analysis is correct, we are left here with the anomaly of explaining why Chesterton and Retté, and others like them, are classed in terms of insularity and reaction. Indeed, if theirs is an immanent frame open to the possibilities of porosity, surely it is those whose immanence is not open, or for whom knowledge of the cosmos is truly mind-centred, who are in its fullest sense insular. By way of sketching a plausible response to this issue, I am by no means trying to settle the question between belief and unbelief. Nor am I denying that such writers belong to a reactionary movement. What is crucial is 
to escape the hegemonic understanding that uses the word reaction as a stick to beat an ideological minority.

Taylor's philosophy of the individual is also of use here, for it is possible to interpret the closure of the reactionary mind itself as a kind of buffering. In the case of those usually designated as reactionaries, however, it is a buffering predicated neither on a mind-centred view of the cosmos, nor on despair about the unavailability of meanings and purposes from without. Rather, it is a buffering which aims at resisting the closed immanent frame as legitimised by cultural conditions in Western Europe since the early modern period. For how, otherwise, can the porosity of the pre-modern, or the openness of the immanent frame, be receptive to exogenous meaning and purpose without being swamped by the range of interpretations that would hold the cosmos to be impersonal in origin, guided by exceptionless laws and devoid of purpose. Just as porosity made unbelief impossible in pre-modern culture, some have the sense that buffering makes belief quasi-impossible in the context of modernity. Weber himself posited that belief required a sacrifice of the intellect.

Still, as I have argued here, that sacrifice is not so much a turning away from the universe but a turning away from the mind-centred view of the universe. Its reaction is in fact a reaching out, and its insularity towards Enlightenment is the condition of retrieving openness within immanence or even of renewing porosity towards a meaningful and purposeful universe. However quotidian and even whimsical it might appear, the window image in the writings of Adolphe Retté and G.K. Chesterton gives expression within two major literary traditions to the same drive to become open again to an exogenous transcendence under the conditions of secularity.

\section{REFERENCES}

${ }^{1}$ G.K. Chesterton, Manalive (London: John Lane, I9I2).

2 G.K. Chesterton, Tremendous Trifles (London: Methuen, I909).

3 G.K. Chesterton, Alarms and Discursions (London: Methuen, I9I0).
4 G.K. Chesterton, 'Orthodoxy' in David Dooley (ed.) Collected Works, Vol 1: Heretics, Orthodoxy, The Blatchford Contro[I908]), pp. 2II-367 (p. 263).

5 G.K. Chesterton, Autobiography (Sevenoaks: Fisher Press, I992 [I936]), p. 29. versies (San Francisco: Ignatius Press, I986
${ }^{6}$ See, for example: Adolphe Retté, Le Règne de la Bête (Paris: Messein, I908), p. 89; Adolphe Retté, Au Pays des lys noirs: souvenirs de jeunesse et d'âge mûr (Paris: Téqui, I9I3), p. 30 I.

7 On Retté's breadth of themes, see Brian Sudlow, Catholic Literature and Secularisation in France and England 1880-1914 (Manchester: Manchester University Press, 20I I).

8 Thomas Woodman, Faithful Fictions: The Catholic Novel in British Literature (Buckingham: Open University Press, I99I), p. Ioo. See also: Richard 
Griffiths, The Reactionary Revolution: The Catholic Revival in French Literature 1870-1914 (London: Constable, I966), p. $7 \mathrm{I}$.

9 See: Don O'Leary, Roman Catholicism and Modern Science: A History (New York and London: Continuum, 2007).

10 G.K. Chesterton, Saint Thomas Aquinas: The Dumb Ox (New York: Image Books/Doubleday, 200I [I933]), p. 6.

11 Charles Taylor, A Secular Age (Cambridge, MA, and London: The Belknap Press of Havard University, 2007), pp. 37-4I.

12 Ian Leask et al. (eds), The Taylor Effect: Responding to a Secular Age (Cambridge: Cambridge Scholars Publishing, 2010).

13 Graham Ward, 'How Literature Resists Secularity', Literature and Theology I (2010) 73-88.

14 William Kenneth Cornell, Adolphe Retté (1863-1930) (New Haven: Yale University Press, I942), p. 29.

15 Adolphe Retté, Cloches en la nuit (Paris: Vanier, I889); Une Belle Dame passa (Paris: Vanier, I893); Campagne première (Paris: Bibliothèque artistique et littéraire, I 897).

16 Adolphe Retté, Le Symbolisme, anecdotes et souvenirs (Paris: Messein, I903).

17 Adophe Retté, La Maison en ordre: Comment un révolutionnaire devint royaliste (Paris: Nouvelle Librairie nationale, I923).

18 Chesterton, Autobiography, p. 77.

19 Ibid., p. 90.

20 G.K. Chesterton, 'Letter to Frances' (c. I 898), in Alvaro de Silva (ed.) Brave New Family: G. K. Chesterton on Men and Women, Children, Sex, Divorce, Marriage and the Family (San Francisco: Ignatius Press, I990), pp. 85-90 (p. 90).

21 William Oddie, Chesterton and the Romance of Orthodoxy: the Making of G.K.C. 1874-1908 (Oxford: Oxford University

22 Chesterton, Autobiography, p. 9I.

23 Georges Shuster, The Catholic Church and Current Literature (London: Burns, Oates and Washburne, I930), p. 7I.

${ }^{24}$ Adolphe Retté, Du Diable à Dieu: histoire d'une conversion (Paris: Messein, I907), pp. $72-3$ and pp. I5I-6.

25 Adolphe Retté, Sous l'Etoile du matin (Paris: Messein, I9Io); Les Rubis du calice (Paris: Messein, 1924).

26 Adolphe Retté, Les Objections aux miracles de Lourdes (Paris: Messein, I910); Lettres à un indifferent (Paris: Bloud and Gay, I92 I).

27 G.K. Chesterton, 'Orthodoxy' in D.J. Dooley (ed.), Collected Works, Vol 1: Heretics, Orthodoxy, The Blatchford Controversies (San Francisco: Ignatius Press, I986 [I908]), 21 I-367 (p. 230).

28 Hugh Kenner, Paradox in Chesterton (London: Sheed and Ward, 1947).

29 Chesterton, 'Orthodoxy', pp. 285-306.

30 Ward, 'How Literature Resists Secularity', p. 77.

31 Ibid., p. 79.

32 G.K. Chesterton, The Well and the Shallows (London: Sheed and Ward, I937), p. 238.

33 G.K. Chesterton, 'The Ballad of the White Horse' in Peter Faulkner (ed.), The Works of G. K. Chesterton (Ware: Wordsworth Poetry Library, I995), pp. I63-24I (p. I64).

34 Ibid., pp. 43-8 (p. 45).

35 Chesterton, Autobiography, p. 29.

36 Retté, Le Règne de la Bête, p. 83. By a curious coincidence, in 1908 as Retté was publishing this novel, Chesterton took up the theme of anarchism in quite different ways in his literary nightmare, The Man who was Thursday.

37 Retté, Au Pays des lys noirs, p. $30 \mathrm{I}$.

38 Adolphe Retté, Dans la lumière d'Ars (Paris: Tolra et Simonet, I9I2), pp. 2 I 8-9.

39 Retté, Au Pays des lys noirs, p. 283.

40 Gregorius Magnus (Adalbert de Vogüé, ed.) Dialogues (Livres I-III): Sources chrétiennes No. 260, Vol. 2, trans. Paul Antin (Paris : Editions du Cerf, I979), pp. 237-9.

41 Chesterton, 'Orthodoxy', p. 237. 
42 Charles Taylor's earlier works include: Sources of the Self: The Making of the Modern Identity (Cambridge, Mass: Havard University Press, 1989); The Ethics of Authenticity (Cambridge, Mass: Havard University Press, I992).

43 Taylor, A Secular Age, pp. 35-43.
44 Ibid., p. 37-42.

45 Ibid., p. 539.

46 I Corinthians, I3:I2 (King James Bible, 10 Oxford Authorized Edition, I769).

47 Ward, 'How Literature Resists Secularity', pp. 77 and 85 . 